\title{
Peran Perawat dalam Pelaksanaan Budaya dalam Lingkup Kerja Perawat untuk Peningkatan Keselamatan Pasien di Rumah Sakit
}

\author{
Lili Evalina \\ lili.evalina@gmail.com
}

\section{Latar Belakang}

Rumah Sakit adalah aset penting bagi seluruh masyarakat, dimana aset ini termasuk ke dalam bagian dari kesatuan organisasi sosial dan kesehatan dan pelayanan yang diberikan disesuaikan dengan jenis intervensi yang diberikan dalam sistem, pelayanan kesehatan serta pendidikan (World Health Organization, 2015). Sehingga dalam hal ini diperlukan kualitas pelayanan yang bermutu dan maksimal dalam memberikan pelayanan kesehatan kepada masyarakat. Hal ini sesuai dengan yang disampaikan Hughes dalam Yulia et al. (2012) bahwa Rumah Sakit akan mengutamakan dalam hal mutu pelayanan dengan berbagai pengembangan program khususnya keselamatan pasien agar membentuk budaya keselamatan pasien yang dilakukan oleh perawat.

Kesehatan dan Keselamatan Kerja (K3) termasuk sebuah upaya gunamenjamin serta menciptakan kesempurnaan baik jasmani maupun rohani dari pihak tenaga kerja, hasil karya dan budayanya menuju masyarakat makmur dan sejahtera. Tujuan diberlakukan K3 adalah agar pekerja memperoleh derajat kesehatan yang tinggi, baik dari segi fisik, mental, maupun sosial dengan berbagai usaha yang dilakukan. Usaha tersebut meliputi preventif dan kuratif terhadap penyakit maupun gangguan kesehatan yang diakibatkan faktor-faktor pekerjaan dan lingkungan kerja, serta terhadap penyakit-penyakit umum (Redjeki, 2016). Sehingga penerapan K3 merupakan salah satu standar pelayanan yang perlu diperhatikan oleh seluruh aspek yang ada di RS.

Berbagai hasil penelitian mengenai keselamatan pasien menunjukkan bahwa terdapat hubungan antara elemen budaya keselamatan dan hasil yang dirasakan oleh pasien. Tingkat keselamatan pasien yang tinggi dapat memberikan manfaat positif bagi pelayanan terhadap pasien juga dapat berpengaruh terhadapabiaya perawatan kesehatan. Peran dari budaya keselamatan pasien sangat dibutuhkan dalam memberikan pelayanan yang bermutu. 
Perawat merupakan salah satu tenagakesehatan yang memiliki peran penting dalam menjalankan fungsi rumah sakit. Hal ini didukung dengan kebutuhan tenaga perawat yang termasuk kedalam jumlah dengan porsiterbesar di pelayanan rumah sakit. Perawat memiliki kontak terbanyak dengan pasien.Akibatnya perawat memiliki potensi terpapar bahaya dan kesalahan dalam memberikan pelayanan.

Perawat adalah tenaga kesehatan yang termasuk dalam komponen penting guna pengembangan program keselamatan pasien di Rumah Sakit. Keselamatan merupakan langkah pertama dalam meningkatkan performa pelayanan yang berkualitas. Pengembangan budaya keselamatan pasien merupakan hal yang sangat penting dalam memberikan pelayanan yang aman dan bermutu (Yulia et al., 2012).Peran perawat dalam mengembangkan mutu pelayanan dengan keselamatan pasien(Hughes, 2008 dalam Yulia et al., 2012).

Kesalahan yang dilakukan oleh perawat dapat terjadi dalam rangkaian asuhan keperawatan yang dimulai dari pengkajian keperawatan, analisa data keperawatan, penarikan diagnosa keperawatan, perencaan keperawatan, pelaksanaan intervensi keperawatan, hingga proses evaluasi keperawatan. Kesalahan yang dapat dilakukan oleh perawat dipengaruhi oleh berbagai faktor. Hal ini perlu diketahui dalam rangka pengembangan mutu pelayanan serta keselamatan pada pasien. Peran perawat dalam memberlakukan budaya keselamatan pasien menjadi salah satu cara dalam meningkatkan mutu dan pelayanan di Rumah Sakit. Sehingga penulis tertarik untuk mengetahui lebih mengenai peran perawat dalam pelaksanaan budaya lingkup kerja untuk peningkatan keselamatan pasien di rumah sakit.

\section{Metode}

Metode yang digunakan dalam penulisan jurnal ini adalah metode kualitatif dengan pendekatan kajian pustaka. Dalam penelitian ini data yang digunakan berasal dari sumber sumber dengan topik yang bersangkutan seperti dari jurnal keperawatan, buku, thesis, skripsi, maupun dari website dan blog dari internet. Dalam arti lain dengan menggunakan kajian pustaka, maka apa yang akan ditulis dalam jurnal ini merupakan hasil dari penelitian terdahulu yang membahas masalah yang sama. Dengan menggunakan metode kualitatif ini juga data yang disampaikan akan berbentuk penulisan dan penjabaran dan tidak dikemas secara statistik. 


\section{Hasil}

Peran perawat dalam melaksanakan budaya lingkup kerja sebagai rangka peningkatan keselamatan pasien di Rumah Sakit sangat diperlukan. Peran serta dari berbagai aspek juga mendukung dalam meningkatkan mutu pelayanan kepada pasien. Salah satu faktor yang berpengaruh adalah motivasi dan peran serta dari perawat kepala ruang. Sejalan dengan penelitian yang dilakukan Hasil penelitian yang dilakukan oleh Nivalinda et al. (2013) menunjukkan terdapat pengaruh antara motivasi perawat dengan gaya kepemimpinan kepala ruang terhadap penerapan budaya keselamatan pasien. Hal ini didukung dengan pernyataan yang disampaikan Shanks dalam Burton (2012) bahwa peran pimpinan dalam memberikan motivasi kepada anggota tim lainnya sangat dibutuhkan mengenai tujuan bersama dalam tim yang telah dibentuk.

Salah satu faktor yang dinilai memiliki pengaruh terhadap penerapan keselamatan kerja oleh perawat adalah pengalaman kerja dari perawat. Hal ini didukung oleh penelitan yang dilakukan oleh Jang et al., (2017) menunjukkan faktor pengalaman kerja berpengaruh dalam budaya keselamatan pasien oleh perawat. Faktor umum yang berpengaruh positif terhadap manajemen keselamatan pasien perawat adalah waktu pengalaman kerja di rumah sakit saat ini serta kejadian kecelakaan tidak terduga mengenai keselamatan pasien, termasuk faktor keamana, persepsi komunikasi, dan frekuensi kejadian yang dilaporkan.

Salah satu bentuk dari penerapan budaya keselamatan pasien adalah perilaku melaporkan insiden. Perilaku dalam melaporkan insiden dapat dikatakan cukup baik sebagai bentuk penerapan budaya keselamatan pasien. Hal ini sesuai dengan hasil penelitian yang dilakukan oleh Anggraeni et al., (2016) bahwa hampir seluruh dari perawat di Instalasi rawat inap Rumah Sakit Tk. II dr. Soepraoen memiliki gambaran budaya keselamatan pasien positif pada seluruh variabel. Terdapat dua variabel yang berpengaruh signifikan dalam penerapan budaya keselamatan pasien yaitu kerja sama antar anggota tim dan keterbukaan komunikasi secara parsial. Sehingga dalam hal ini pengaruh eksternal juga berpengaruh dalam peran seorang perawat dalam penerapan budaya kerja dalam keselamatan pasien.

Peran perawat dalam hal melaksanakan budaya lingkup kerja untuk meningkatkan keselamatan pasien sudah cukup baik. Namun, terdapat perbedaan hasil pada penelitian yang di Oman menunjukkan bahwa budaya keselamatan belum ditetapkan dan dikembangkan. Sehingga diperlukan inisiatif untuk meningkatkan komunikasi, kerja tim, pelaporan kesalahan, dan respons 
terhadap kesalahan. Pelaporan kesalahan harus dilihat sebagai strategi untuk belajar dari kesalahan dan langkah awal untuk menciptakan budaya keselamatan pasien (Ammouri et al., 2015).

Hasil berbeda ditunjukkan pada penelitian yang dilakukan di Indonesia. Hasil yang ditunjukkan pada penelitian yang dilakukan di salah satu RS Aceh bahwa perilaku sebagian besar perawat pelaksana sudah baik dalam menerapkan manajemen Kesehatan dan Keselamatan Kerja (K3) dalam hal ini sebagai bentuk peningkatan keselamatan pasien. Hal ini ditunjukkan dengan dari faktor internal (52.5\%) maupun faktor eksternal (58.8\%) (Nazirah \& Yuswardi, 2017). Hasil penelitian yang menunjukkan faktor yang mempengaruhi kepatuhan perawat di RS Pemerintah Yogyakarta mengenai standar kewaspadaandalam hal ini adalah motivasi serta pengalaman kerja, dimana faktor yang paling mempengaruhi standar kewaspadaan sebagai penerapan K3 yaitu motivasi (Sagita, 2019).

Dalam rangka meningkatkan peran perawat sebagai bentuk pelaksanaan budaya lingkup kerja untuk meningkatkan keselamatan pasien, pihak Rumah Sakit dengan mengadakan pelatihan untuk perawat. Hasil penelitian yang dilakukan olehYulia et al. (2012) bahwa dengan memberikan pelatihan keselamatan pasien bagi perawat pelaksana dapat meningkatkan tingkat pengetahuan dalam melaksanakan budaya keselamatan bagi pasien. Namun, dalam penelitian ini tidak ada pengaruh internal dari seorang perawat pelaksana dalam menerapkan budaya keselamatan pasien.

\section{Pembahasan}

Budaya keselamatan merupakan keyakinan, nilai, serta perilaku yang dipercaya olehseseorang dalam sebuah organisasi terhadap keselamatan yang mengedepankan dan mendukung dalam peningkatan keselamatan.Budayakeselamatan pasien merupakan persepsi, nilai sikap,persepsi, kompetensi serta pola perilaku dari individudan kelompok yang menentukan komitmen dan cara organisasi dalam keselamatan pasien. Budaya keselamatan pasien terdiri dari beberapa elemen yang harus diperhatikan. Elemen-elemen yang ada dalam budayakeselamatan pasien adalahpelaporan (reporting), penerapan budaya komunikasi yang terbuka (open), perlakuan yang adil (just), pembelajaran (learning) dan pemberian informasi (informed) (Nivalinda et al., 2013).

Hubungan antara elemen budaya keselamatan dan hasil yang dirasakan oleh pasien. Tingkat keselamatan pasien yang tinggi dapat mempengaruhi hasil pasien yang juga berpengaruh 
terhadap pengurangan biaya perawatan kesehatan. Peran dari budaya keselamatan pasien sangat dibutuhkan dalam memberikan pelayanan yang bermutu. Sehingga terdapat kepercayaan dari pasien terhadap Rumah Sakit mengenai pelayanan yang diberikan.

Sebagai bagian dari tenaga kesehatan yang bertugas di Rumah Sakit, perawat termasuk dalam komponen penting guna pengembangan program keselamatan pasien di Rumah Sakit. Keselamatan merupakan langkah utama dari usaha yang dilakukan untuk meningkatkan pelayanan yang berkualitas dan bermutu. Pengembangan budaya keselamatan pasien merupakan hal penting yang perlu diperhatikan dari pelayanan yang aman dan bermutu.Rumah Sakit akan mengutamakan dalam hal mutu pelayanan dengan berbagai pengembangan program keselamatan dan lingkungan kerja agar membentuk budaya keselamatan oleh perawat. Peran perawat dalam mengembangkan mutu pelayanan dengan keselamatan pasien sangat dibutuhkan (Hughes, 2008, dalam Yulia et al. (2012).

Terdapat beberapa faktor yang mempengaruhi peran perawat dalam melaksanakan budaya lingkup kerja untuk meningkatkan keselamatan pasien. Salah satu faktor yang berpengaruh adalah motivasi dan peran serta dari perawat kepala ruang untuk meningkatkan mutu pelayanan kepada pasien. Sejalan dengan penelitian yang dilakukan oleh Nivalinda $e t$ al. (2013) menunjukkan adanya pengaruh antara motivasi perawat dengan gaya kepemimpinan kepala ruang terhadap penerapan budaya keselamatanpasien. Hal ini menunjukkan bahwa dalam membentuk budaya keselamatan yang maksimal dipengaruhi oleh kepemimpinan yang kuat, motivasi dan kedisiplinan individu dalam kinerja keselamatan pasien serta sistem manajemen sumber daya manusia. Dalam hal ini fokus utama dalam menerapkan budaya keselamatan pasien adalah dengan memerhatikan berbagai prosedur manajemen serta perilaku kinerja dalam keselamatan pasien yang berhubungan dengan pengawasan, kedisiplinan individu dan kepemimpinan yang efektif.

Motivasi perawat dalam memberikan pelayanan berupa asuhan keperawatan dan menjalankan budaya keselamatan pasien dipengaruhi oleh berbagai faktor. Faktor-faktor yang diyakini dapat mempengaruhi motivasi perawat adalah keinginan untuk mengalami berbagai peningkatan dari segala aspek, rasa percaya bahwa gaji yang dimiliki sudah mencukupi, memiliki kemampuan serta pemahaman dari perawat, keterampilan serta nilai-nilai yang diperlukan dalam menjalankan tugas, terdapat umpan balik dari pasien,kesempatan dalam 
mencoba pendekatan baru untuk melakukan pekerjaan, promosi kerja, kerja sama antara anggota tim, dan peningkatan penghasilan (Suarli et al., 2009 dalam Nivalinda et al., 2013).

Faktor internal lainnya adalah pengalaman kerja dari perawat itu sendiri. Hal ini sesuai dengan hasil penelitian yang dilakukan oleh Jang et al., (2017) menunjukkan faktor pengalaman kerja. Penelitian ini menunjukkan beberapa faktor yaitu waktu pengalaman kerja di rumah sakit saat ini serta kejadian kecelakaan tidak terduga mengenai keselamatan pasien, termasuk faktor keamanan, persepsi komunikasi, dan frekuensi kejadian yang dilaporkan. Studi ini juga memberikan sebuah solusi untuk mempromosikan aktivitas manajemen keselamatan pasien di rumah sakit. Dengan adanya penelitian ini dapat memberikan latar belakang dasar untuk strategi intervensi pendidikan keperawatan untuk mempromosikan pengendalian keselamatan dan kegiatan manajemen keselamatan pasien yang ditujukan untuk perawat. Namun, hasil lain ditunjukkan pada penelitian yang dilakukan di Oman bahwa budaya keselamatan belum ditetapkan dan dikembangkan. Sehingga diperlukan inisiatif untuk meningkatkan budaya keselamatan pasien (Ammouri et al., 2015).

Peran perawat pelaksana khususnya dalam melakukan budaya dalam lingkup kerja guna meningkatkan keselamatan pasien adalah melaporkan setiap insiden yang terjadi dalam pemberian asuhan keperawatan secara detail dan jujur. Berdasarkan penelitian yang digunakan dalam literatur ini peran perawat dalam melaksanakan perannya sudah baik. Hal ini ditunjukkan dari hasil penelitian yang dilakukan oleh Anggraeni et al., (2016) bahwa hampir seluruh dari perawat di Instalasi Rawat Inapdi Rumah Sakit Tk. II dr. Soepraoen menunjukkan gambaran budaya keselamatan pasien positif dari seluruh variabel yang digunakan dalam penelitian. Terdapat dua variabel yang berpengaruh signifikan dalam penerapan budaya keselamatan pasien yaitu kerja sama antar anggota tim dan keterbukaan komunikasi secara parsial. Sehingga dalam hal ini pengaruh eksternal juga berpengaruh dalam peran seorang perawat dalam penerapan budaya kerja dalam keselamatan pasien.

Peran perawat dalam hal melaksanakan budaya lingkup kerja untuk meningkatkan keselamatan pasien masih kurang. Hasil penelitian yang di Oman oleh Ammouri et al. (2015)menunjukkan budaya keselamatan belum ditetapkan dan dikembangkan. Sehingga diperlukan inisiatif untuk meningkatkan komunikasi, kerja tim, pelaporan kesalahan, dan respons terhadap kesalahan. Peran perawat dalam hal melaporkan kesalahan merupakan sebuah strategi bagi perawat dalam belajar dari kesalahan dan langkah awal untuk menciptakan budaya 
keselamatan pasien. Perilaku ini perlu diterapkan bukan hanya dari perawat saja, namun dari seluruh tenaga kesehatan yang berperan di Rumah Sakit guna memaksimalkan pemberian pelayanan kepada pasien.

Perilaku perawat dalam penerapan budaya keselamatan pasien di RS cukup baik. Hal ini didukung dengan hasil penelitian yang dilakukan Nazirah dan Yuswardi (2017) di RS Aceh menunjukkan sebagian besar perawat pelaksana menunjukkan perilaku yang baik dalam menerapkan Kesehatan dan Keselamatan Kerja (K3) sebagai bentuk budaya keselamatan pasien. Hal ini terliaht dari faktor internal (52.5\%) maupun faktor eksternal (58.8\%). Persepsi merupakan salah satu faktor internal yang hasilnya baik. Persepsi perawat tentang K3 menunjukkan bagaimana perawat mampu mencari tahu tentang pentingnya K3 baik melalui SOP, leaflet, brosur yang disediakan di ruangan maupun media informasi lainnya. Perawat juga dituntut dapat memahami bagaimana cara pencegahan kecelakaan serta penanganan yang dapat dilakukan apabila kecelakaan terjadi. Pemahaman tersebut akan menimbulkan persepsi yang baik dalam diri perawat tentang K3 sehingga hal ini akan meningkatkan perilakunya dalam menjaga keselamatan.

Melihat pentingnya peran perawat dalam melaksanakan budaya lingkup kerja guna meningkatkan keselamatan diperlukan intervensi berupa pelatihan bagi seluruh tenaga kesehatan mengenai keselamatan pasien. Penelitian yang dilakukan oleh Yulia et al. (2012) menunjukkan bahwa dengan pemberian pelatihan keselamatan pasien bagi perawat pelaksana dapat meningkatkan tingkat pengetahuan dalam melaksanakan budaya keselamatan pasien. Hal ini didukung oleh pernyataan yang disampaikan oleh Suryabrata dalam Yulia et al. (2012) bahwa proses belajar dalam hal ini pelatihan yang diberikan dalam meningkatkan pengetahuan dapat mempengaruhi perilaku secara aktual dan potensial Sehingga, terdapat pengaruh langsung dari proses pelatihan terhadap pemahaman dari tenaga keperawatan dari salah satu Rumah Sakit yang diteliti.

Hasil dari penelitian sebelumnya menunjukkan tidak ada pengaruh internal dari seorang perawat pelaksana dalam menerapkan budaya keselamatan pasien. Pengalaman kerja yang dimiliki oleh perawat menjadikan kinerja yang dilakukan dalam memberikan asuhan keperawatan kepada pasien dengan cara yang profesional. Dalam hal ini perawat memiliki kemungkinan untuk mengedepankan kepentingan pasien dan peran profesi perawat dalam memberikan pelayanan. 


\section{Penutup}

Peran perawat dalam hal pelaksanaan budaya lingkup kerja guna meningkatkan keselamatan pasien di rumah sakit sangatlah penting. Terdapat beberapa faktor yang mempengaruhi peran seorang perawat dalam memaksimalkan budaya keselamatan pasien. Motivasi serta peran dari perawat dari kepala ruangan mampu meningkatkan peran dari seorang perawat. Selain itu, pengalaman kerja dari seorang perawat juga mampu memberikan kinerja maksimal dalam melaksanakan asuhan keperawatan dan budaya keselamatan pada pasien. Perilaku dari perawat mengenai pelaporan setiap insiden juga diperlukan guna meningkatkan mutu pelayanan dari Rumah Sakit.

Keterlibatan dari seluruh pihak Rumah Sakit perlu dilakukan, dalam hal ini peran perawat sebagai kunci utama. Pemberian pelatihan kepada seluruh tenaga keperawatan mampu meningkatkan peran perawat dalam melaksanakan budaya lingkup kerja yang memiliki manfaat dalam memaksimalkan budaya keselamatan pasien di pelayanan Rumah Sakit. Diperlukan juga penelitian lebih lanjut mengenai kurikulum pelatihan yang dapat digunakan untuk memaksimalkan peran perawat, sehingga mutu dari pelayanan Rumah Sakit dapat dilakukan secara maksimal. 


\section{DAFTAR PUSTAKA}

Ammouri, A. A., Tailakh, A. K., Muliira, J. K., Geethakrishnan, R., \& Al Kindi, S. N. (2015). Patient safety culture among nurses. International Nursing Review, 62(1), 102-110. https://doi.org/10.1111/inr.12159

Burton, K., (2012). A study of motivation: how to get your employees moving. Thesis: Indiana University.

Dewi Anggraeni, Ahsan, \& Azzuhri, M. (2016). Pengaruh Budaya Keselamatan Pasien terhadap Sikap Melaporkan Insiden pada Perawat di Instalasi Rawat Inap Rumah Sakit Tk. II dr. Soepraoen. Jurnal Aplikasi Manajemen, 14(2), 309-321. https://doi.org/10.18202/jam23026332.14.2.13

Jang, H.-E., Song, Y., \& Kang, H.-Y. (2017). Nurses' Perception of Patient Safety Culture and Safety Control in Patient Safety Management Activities. Journal of Korean Academy of Nursing Administration, 23(4), 450. https://doi.org/10.11111/jkana.2017.23.4.450

Nazirah, R., \& Yuswardi. (2017). PERILAKU PERAWAT DALAM PENERAPAN MANAJEMEN KESEHATAN DAN KESELAMATAN KERJA (K3) DI ACEH. Idea Nursing Journal, 8(3), 1-6.

Nivalinda, D., Hartini, M. C. I., \& Santoso, A. (2013). Perawat Pelaksana pada Rumah Sakit Pemerintah di Semarang. Jurnal Managemen Keperawatan, 1(2), 138-145.

Redjeki, S. (2016). Kesehatan dan Keselamatan kerja. BPPSDMK Kementerian Kesehatan RI. http://bppsdmk.kemkes.go.id/pusdiksdmk/wp-content/uploads/2017/08/Kesehatan-danKeselamatan-Kerja-Komprehensif.pdf

Sagita, R. W. (2019). Factors Affecting Nurses' Compliance in Implementing Standard Precautions in Government Hospital in Yogyakarta. Indonesian Contemporary Nursing Journal (ICON Journal), 3(2), 1. https://doi.org/10.20956/icon.v3i2.4972

Simamora, R. H. (2018). Buku ajar keselamatan pasien melalui timbang terima pasien berbasis komunikasi efektif: SBAR. Medan: USUpress. 
Simamora, R. H. (2020). Learning of Patient Identification in Patient Safety Programs Through Clinical Preceptor Models. Medico Legal Update, 20(3), 553-556.

World Health Organization. (2015). Comprehensive Safe Hospital Framework. In Who.

Yulia, S., Hamid, A. Y. S., \& Mustikasari, M. (2012). Peningkatan Pemahaman Perawat Pelaksana dalam Penerapan Keselamatan Pasien Melalui Pelatihan Keselamatan Pasien. Jurnal Keperawatan Indonesia, 15(3), 185-192. https://doi.org/10.7454/jki.v15i3.26 